\title{
DYNAMIC INTERACTION BETWEEN HOUSE PRICES AND STOCK PRICES IN MALAYSIA
}

\author{
Hooi Hooi LEAN ${ }^{a}{ }^{*}$, Russell SMYTH ${ }^{b}$ \\ a School of Social Sciences, Universiti Sains Malaysia, 11800 USM, Penang, Malaysia \\ ${ }^{b}$ Department of Economics, Monash University, Australia
}

Received 25 October 2012; accepted 10 April 2013

\begin{abstract}
This paper examines the dynamic linkages between house price indices, interest rates and stock prices in Malaysia using cointegration and Granger causality testing. For Malaysia as a whole, we find that house prices, stock prices and interest rates are not cointegrated. For Kuala Lumpur, Penang and Selangor we find that house prices, stock prices and interest rates are cointegrated for $40 \%$ of the house price indices. When there is evidence of cointegration in these regions, we find that stock prices lead house prices. While there are alternative potential reasons for this finding, such as slow adjustment of house prices in response to a shock in the fundamentals, it is consistent with a wealth effect. A likely explanation for this result is that in these states, compared with the Malaysian average, housing is expensive, income is high and real estate is used much more as an investment vehicle by both wealthy Malaysians and foreigners leveraging of the share market.
\end{abstract}

KEYWORDS: House prices; Interest rates; Stock prices; Malaysia.

REFERENCE to this paper should be made as follows: Lean, H. H.; Smyth, R. 2014. Dynamic interaction between house prices and stock prices in Malaysia, International Journal of Strategic Property Management 18(2): 163-177.

\section{INTRODUCTION}

Housing and stocks can be considered as investment alternatives. Both real estate and stocks are often important assets in many investors' portfolios. Several authors have argued that commercial real estate offers diversification benefits to institutional investors because of its low correlation with commonly used stock price indices (see e.g. Quan, Titman 1999) ${ }^{1}$. Several explanations have been proposed to explain the potential dynamic interaction between house and stock prices (Kapopoulos, Siokis 2005; Piazzesi et al. 2007).

One mechanism is the wealth effect, which suggests that households with unanticipated gains in share prices will increase the amount of hous-

\footnotetext{
* Corresponding author. E-mail: hooilean@usm.my

${ }^{1}$ However, it is to be noted that the simple correlation between the real estate-based stocks and the aggregate stock index is not low (0.87) in Malaysia.
}

ing. Hence, the stock market will lead the housing market. This will occur through two channels because housing is both a consumption and investment good. One channel is that an increase in share market wealth will result in an increase in aggregate consumption. The other channel is through investment portfolio adjustment. When share prices increase, the share of households' portfolios in the stock market will increase and households will seek to rebalance their portfolios through selling stocks and purchasing other assets, including housing (Markowitz 1952).

Second, stock prices may have an impact on house prices through channels other than wealth exposures. Stock prices are likely to reflect firms' profitability and profit-related remuneration of employees, such as bonuses. Hence, an increase in stock prices will generate an increase in the demand for housing as both a consumption and in- 
vestment good, which will, in turn, result in higher housing prices (see e.g. Green 2002).

A third mechanism linking housing and stock prices is the credit-price effect, which focuses attention on the balance sheet position and collateral value of credit constrained firms. Since commercial and residential property can act as collateral for loans, when real estate prices increase, credit constrained firms are able to borrow more for investments. The credit-price effect tends to suggest that the housing market will lead the stock market because firms holding commercial real estate will have large unrealized capital gains that will mean that investors will bid up the equity value of the firm. However, since firms demand more land and buildings to carry out expanded investment, the price of property will also increase, suggesting an upward spiral in both property and stock prices and persistent feedback effects.

A fourth mechanism is composition risk, which relates changes in consumption expenditure to asset prices. Consumption-savings decisions depend not only on the size of future consumption, but also on their composition between housing and other consumption. During recessions, because investors expect higher future consumption, they sell stocks now to increase current consumption, which drives stock prices down. This inter-temporal substitution mechanism drives stocks down in bad times. Piazzesi et al. (2007) present a model in which investors' concern with composition risk implies that the size of the inter-temporal effect will depend on the share of housing in consumption. Recessions will be particularly severe when the share of housing consumption is low. Their model also implies low frequency swings in stock prices because the housing share changes slowly over time.

Fifth, sluggish and autocorrelated adjustment of housing prices to shocks in the fundamentals is likely to create lead-lag relations between stock and housing price movements. Because housing prices are slower than stock prices to adjust to shocks in the economic fundamentals, the leadlag relations identified by Granger causality can be due simply to the slow adjustment of the housing market. To put it differently, while economic fundamentals are important factors responsible for movements in housing prices, housing prices might react slowly to shocks in the fundamentals (see e.g. Clayton 1996; Himmelberg et al. 2005).

Several studies have examined the relationship between real estate prices and stock prices (see e.g. Chen 2001; Sutton 2002; Green 2002; Sim, Chang 2006). Most of these studies, however, are for developed countries. There are few studies of this sort for developing countries and those which exist are recent (see e.g. Liu, Su 2010; Ibrahim 2010; Ciarlone 2011; Gharaibeh, Alrabadi 2012; T. C. Lin, Z. H. Lin 2011). Further studies for developing countries are important for several reasons (Ciarlone 2011). Developing countries are becoming an engine for world growth. Because of increasingly integrated capital markets, developments in their housing markets can have as serious consequences for stock markets as in developed economies. Many developing economies have experienced substantial real increases in housing prices, often fuelled by rapid expansion in credit. There is a lot of interest in how this relates to movements in stock prices, particularly in developing Asia (T. C. Lin, Z. H. Lin 2011). Finally, findings from developing countries are mixed, suggesting further research is needed. For example, Ibrahim (2010) finds evidence for a wealth effect in Thailand, while Ciarlone (2011) finds support for a wealth effect for a panel of 17 emerging economies. However, Liu and Su (2010) find mixed evidence of credit price and wealth effects in China. T. C. Lin and Z. H. Lin (2011) reach similar conclusions for six Asian countries. Gharaibeh and Alrabadi (2012) find that real estate and stock prices are segmented in Dubai.

This paper extends this literature through examining the dynamic linkages between the real estate market and stock market for Malaysia. There are no studies for Malaysia. A major motivating reason for studying house and stock prices in Malaysia is recent interest in movements in these asset prices in that country. Most interest in this issue in Malaysia centres on whether movements in housing prices and stock prices represent a financial bubble (Bryson, Kamaruddin 2010; Khan 2010). The movement in housing and stock prices in Malaysia, in the lead up to, during and following, the Global Financial Crisis (GFC) has raised the issue of whether one market is leading the other or if there are feedback effects between the markets. Another reason for studying the interaction between house prices and stock prices in Malaysia is that it adds to the embryonic literature on real estate price and stock price interaction for other developing countries and adds to our understanding of the dynamic interaction between housing and stock markets more generally.

Specifically, in addition to testing the potential dynamic interaction between house and stock prices for Malaysia as a whole, we do so for the specific states/territories of Kuala Lumpur, Penang and Selangor. These are the three most economi- 
cally developed regions of Malaysia and areas in which investment and trading activities in housing markets are most active. In each case, in addition to using an aggregate price index for all housing, we use price indices for specific types of housing; namely, detached, semi-detached, terrace and high-rise housing separately. This is important because the strength of the lead-lag relationship between housing and stock prices will depend on the extent to which purchasing real estate is considered an investment and investors might treat different sorts of housing differently.

Consistent with the most recent studies on this topic (Chen 2001; Ibrahim 2010), we employ a unit root, cointegration and Granger causality testing framework. Because the housing and stock markets have been potentially subject to structural breaks, such as the property boom and GFC over the period we examine, we allow for a structural break in the unit root test and take account of the impact of the structural break in our choice of cointegration test. While our primary focus is on the relationship between prices in real estate and stock markets, employing bivariate analysis is not satisfactory because the relationship between the variables might be spurious reflecting common factors (Quan, Titman 1999; Ibrahim 2010). This suggests that other control variables need to be added. We use the interest rate, which is likely to be a key determinant of an investor's ability to borrow to finance investment in the housing market and stock market (Chen 2001). The availability of credit has been shown to be important in reinforcing boombust cycles in asset markets (see Oikarinen 2009).

\section{EXISTING LITERATURE}

Most of the early studies which examined the relationship between real estate prices and stock prices were for the United Kingdom or the United States and focused on correlations between the two assets returns (see e.g. Ibbotson, Siegel 1984; Hartzell 1986; Worzala, Vandell 1993; Eichholtz, Hartzell 1996; Gyourko, Keim 1992). There are also studies for countries other than the United Kingdom and United States, such as Hong Kong (Fu, Ng 2001) and Switzerland (Hoesli, Hamelink 1997). The evidence on the contemporaneous correlation between housing and stock prices in these studies is mixed. Studies such as Ibbotson and Siegel (1984), Hartzell (1986), Worzala and Vandell (1993) and Eichholtz and Hartzell (1996) found the correlation between housing and stock returns to be negative. Other studies have found a contemporaneous posi- tive correlation between housing and stock returns (see e.g. Gyourko, Keim 1992; Fu, Ng 2001; Hoesli, Hamelink 1997). However, whether positive or negative, the correlations have been found to be sufficiently low to imply significant diversification opportunities (Oikarinen 2010).

However, most of these studies provide no indication whether the stock market leads the housing market or vice-versa because no inference can be made about the direction of causation. One set of studies has examined the short-run dynamics between house prices and stock prices using Granger causality or impulse response functions. There are studies by Chen (2001), using Taiwanese data; Takala and Pere (1991), using Finnish data; Green (2002), using data from four geographic regions in California with different housing prices; Kakes and Van Den End (2004), using data from the Netherlands; and Kapopoulos and Siokis (2005), using data from Greece. Sutton (2002) examined the short-run dynamics between housing prices and stock prices for Australia, Canada, the United Kingdom, the United States, Ireland and Netherlands using Granger causality testing. These studies have generally found that in the short-run stock prices lead, or predict, housing prices.

There are very few studies that have examined long-run interdependence between stock and housing prices. This is despite the fact that the longterm dynamic relationship between house and stock prices is of particular importance because real estate investment is typically a long-term investment due to its large transaction costs (Oikarinen 2010). There is evidence that dynamic interdependencies between asset prices may improve co-variation in the long-run. For example, Englund et al. (2002) presented evidence to suggest that the investment horizon does matter. These authors analyzed the composition of household investment portfolios containing housing, common stocks, stocks in real estate holding companies, bonds and $t$-bills. For short periods their conclusion is that the efficient portfolio allocation is to hold no assets in housing, but for longer periods low-risk portfolios should contain anywhere between 15-50\% housing. Englund et al. (2002) estimated the correlation coefficients by a VAR model. As Oikarinen (2010) noted, if house prices and stock prices are cointegrated, Englund et al. (2002) would have underestimated the true horizon effect.

Among the few studies to examine whether there is a long-run relationship between house prices and stock prices, Barot and Takala (1998) and Takala and Pere (1991) found that there is a 
long-run cointegrating relationship in Finland using quarterly data between 1970 and 1990. Using quarterly data between 1970 and 2006, Oikarinen (2010) found that a long-run relationship between housing prices and stock prices continued to exist after the abolition of controls on foreign ownership of stocks in Finland in 1993; however, the growth in foreign ownership of shares has induced a large, and long-lasting, deviation between housing and stock prices. Chou and Chen (2011) examined the relationship between stock and real estate markets in the United States using wavelet analysis and find mixed evidence of credit price and wealth effects. Hui and $\mathrm{Ng}$ (2012) used cointegration and Granger causality to examine the relationship between housing prices and stock prices in Hong Kong. They found some support for a credit price effect, but over time this disappeared and the markets became segmented. Some of the recent studies for developing countries have used cointegration and Granger causality to examine the relationship between housing prices and stock prices (see e.g. Ibrahim 2010; T. C. Lin, Z. H. Lin 2011; Liu, Su 2010; Gharaibeh, Alrabadi 2012). However, as discussed above, these results suggest conflicting evidence of credit price and wealth effects as well as some support for market segmentation. The results differ for different emerging economies in Asia and the Middle East and across time periods. In a related study, Guo and Huang (2010) found that speculative capital inflow or 'hot money' into China has contributed to volatilities in China's housing market and stock market.

To summarize, a few key features of the existing literature emerge. First, most of the literature which has examined the relationship between house prices and stock prices has explored the contemporaneous correlation between the two prices or the short-run dynamics using Granger causality. There are relatively few studies which have examined the long-run dynamics between house and stock prices. Second, there are relatively few studies of the dynamic linkages between real estate and stock markets for developing markets and no studies for Malaysia. This is in spite of recent intense interest in movements in housing price and stock price movements in Asia generally and Malaysia more specifically.

\section{THE MALAYSIAN CONTEXT}

Malaysia experienced a relatively high rate of economic growth in the lead-up to the GFC. Between 2006 and 2008, Malaysia's annual average growth rate was $5.7 \%$ per annum. The Malaysian economy contracted by $1.7 \%$ in 2009 amid the $2008-2009$ global economic slowdown, before rebounding to growth of $7.2 \%$ in 2010 (EIU 2011). Housing prices and stock prices showed strong growth prior to the GFC. Both fell in the aftermath of the GFC, but both housing prices and stock prices have strongly rebounded in parallel following the crisis. Prior to the GFC, the Kuala Lumpur Composite Index (KLCI) finished 2007 on 1,445 points, up from 1,096 points at the end of 2006 (World Bank 2008). At the height of the GFC, on March 10, 2008 alone the KLCI dropped 9.5\% (World Bank 2008). However, since the GFC, the KLCI has rebounded strongly and in January 2011, the KLCI reached an all time historic high of 1,533 points.

Since the GFC, in Malaysia housing prices have increased sharply, particularly in Kuala Lumpur, the Klang Valley (comprising Kuala Lumpur and its suburbs and adjoining cities and towns in Selangor) and Penang. In 2010 property prices in Kuala Lumpur and Penang increased between 10\% and $30 \%$ within a period of 18 months (Sivalingam 2011). House prices continued to grow, but at a slower pace, due to a slight drop in economic growth rates, in 2011. In 2011 the national house price index increased $6.1 \%$. In Selangor house prices increased $8.9 \%$ in 2011, while house prices in Kuala Lumpur increased 6\% in 2011 (Williams et al. 2012).

There are several reasons for the increase in housing prices. First, there has been an increase in foreign acquisition of property in Malaysia. The Malaysian government is keen to attract more foreign property investors, particularly from India, Singapore and the United Kingdom. Malaysia's Foreign Investment Committee has deregulated investment guidelines with a view to making it easier for foreigners to purchase property. To this point, foreign investors from India, Korea, Singapore and the United Kingdom have been the biggest investors in Malaysia, investing on average US $\$ 150,000$ to US $\$ 300,000$ with Kuala Lumpur, Penang and Selangor, among the most popular destinations ${ }^{2}$. This has stimulated prices at the high end of the market, in particular in these locations. Foreign investment in the high-end condominium market has fuelled the Greater Kuala Lumpur Mass Rapid Transit system in the Klang Valley, which will be an integrated rail network comprising two northeast-southwest radial lines

\footnotetext{
2 'Malaysia keen to attract overseas property investors as analysts predict steady real estate recovery' http:// www.propertywire.com/news/asia/malaysia/real-estate market [last accessed 19 July 2010]
} 
and one circle loop around central Kuala Lumpur. It was announced in June 2010 and approved by the Malaysian government in December 2010. While it has not yet been completed, there has been a lot of foreign investment on the back of its potential benefits.

Second, a range of schemes exist to assist new homeowners to get a foothold in the housing market and help existing homeowners move up the property ladder. These schemes have created extra demand, putting upward pressure on prices. There have been a range of flexible mortgages available coupled with low interest rates to stimulate economic growth, following the GFC. These institutional developments have potentially been very important in explaining house price dynamics in Malaysia. Ortalo-Magne and Rady (2006) presented a life-cycle model of the housing market with a property ladder and credit constraint. Their model suggests that a powerful driver of the housing market is the ability of young households to afford the down payment on a first home. Ortalo-Magne and Rady (2006) also showed that down payment constraints on households affect the transmission of income shocks to house prices. Specifically, the volatility in the income of first homebuyers and the ability of first homebuyers to trade up is an important factor contributing to volatility in house prices. In Malaysia, in response to these institutional changes relaxing credit constraints, there has been substantial property development with increased volatility in the market.

Third, Malaysia is a developing country which has undergone rapid urbanization and demographic change as a result of structural change in the economy. The urbanization rate was $38.8 \%$ in 1980 before almost doubling to $62 \%$ in 2000 and $66.9 \%$ in 2005 (Ho 2008). Such trends create excess demand for housing and push up prices (Hui 2009). Demographic statistics from Ng (2006) suggested that the population in Malaysia consists of a much larger number of working adults than retirees. Over $60 \%$ of the population are in the working age group of $15-64$, while less than $5 \%$ of the population are over 65 years of age. This implies that a bigger pool of first-time buyers and up-graders exists relative to the pool of households trading down, which push prices up (Hui 2009).

\section{DATA}

We used the Malaysian house price index data published by the National Property Information Centre (NAPIC) over the period 2000Q1 to 2010Q3. It contains quarterly house price indices for Malaysia as a whole as well as for specific locations. The house price index is based in 2000 so that each index equals 100 in 2000. A weighted average procedure was used to derive the overall indices for terraced houses, high-rise housing and aggregate overall housing at the state and national levels. The sample period is dictated by data availability. We used house price indices for Malaysia as a whole as well as Kuala Lumpur, Penang and Selangor. In each case we used price indices for housing as a whole as well as detached, semi-detached, terrace and high-rise housing. To measure the interest rate, we used the base lending rate $(\mathrm{BLR})$ and to measure stock prices, we used the KLCI. We used the BLR instead of alternatives such as T-bills, primarily because the BLR is the reference rate for borrowing, especially for the housing mortgage rate. While underlying interest rates fluctuate more than the BLR, we use quarterly data where the BLR has fluctuated over time (see Fig. 1). Using the KLCI as the Malaysian stock price index does have the limitation that the KLCI does not account for households who have wealth in investments in foreign stocks. Data on the BLR and KLCI were collected from Datastream. All data were transformed to natural logs.

Fig. 1 shows the time series plots for interest rates, stock prices and house prices. The KLCI has generally increased over time with a trough in the GFC. House prices for Malaysia and the three states/territories have exhibited a positive trajectory over time. Table 1 presents descriptive statistics of house price changes, interest rates and stocks prices. For the all housing price changes, Kuala Lumpur has the highest mean followed by Penang and Selangor. House price changes in both Kuala Lumpur and Penang are higher than for Malaysia as a whole. Turning to specific types of housing, price changes for Kuala Lumpur detached have the highest mean while price changes for Penang detached have the lowest mean. In Penang, price changes for high-rise housing have the second highest mean, but price changes for high-rise housing in Selangor and Kuala Lumpur have the lowest mean. That high-rise housing in Penang is more expensive than in Kuala Lumpur and Selangor reflects the fact that land is more limited in Penang. The Real Estate and Housing Developers' Association in Penang claimed that the high cost of land in Penang is the main reason for the high cost of high-rise luxury condominiums in that state. Land owners command a high price and this is passed on by developers in the form of higher housing prices (Mun 2010). 
BLR
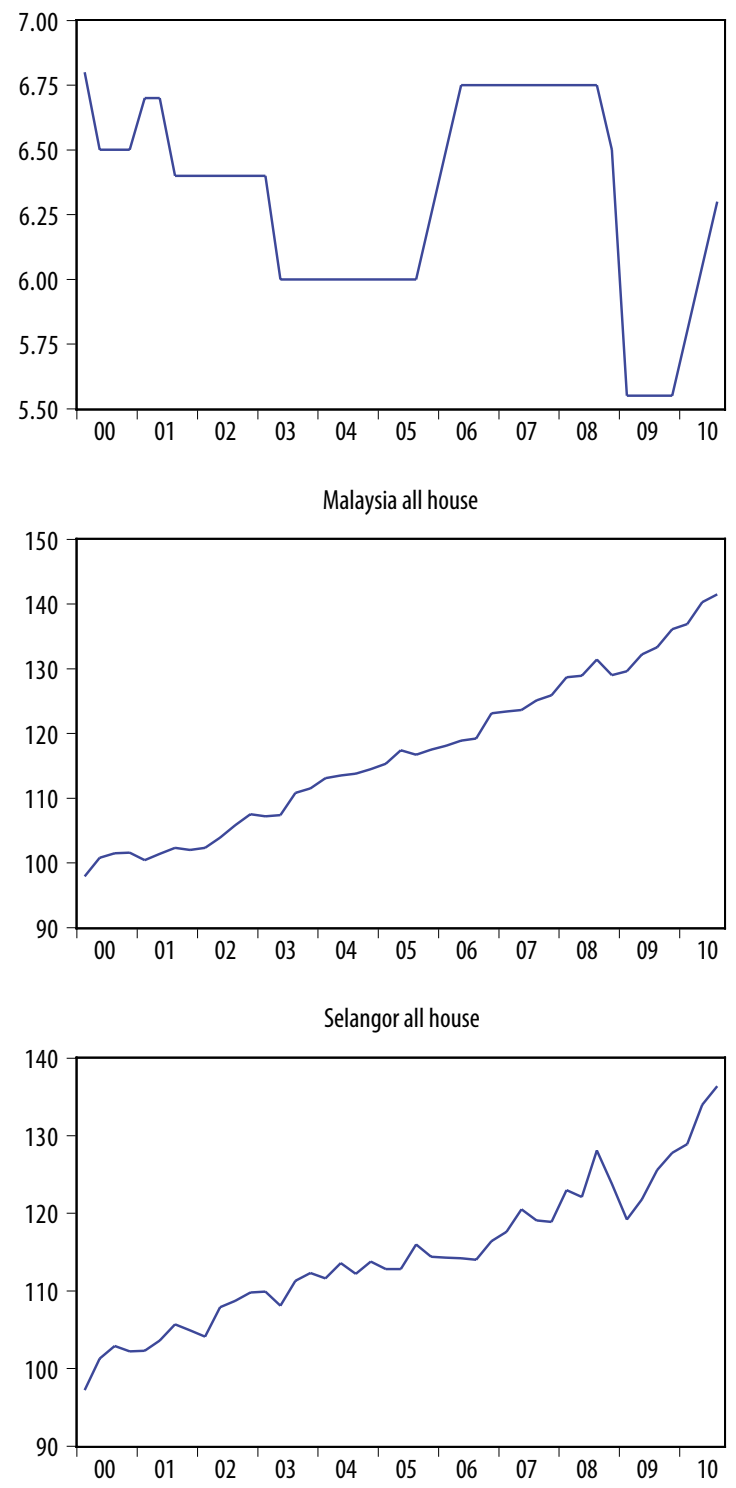

KLCI
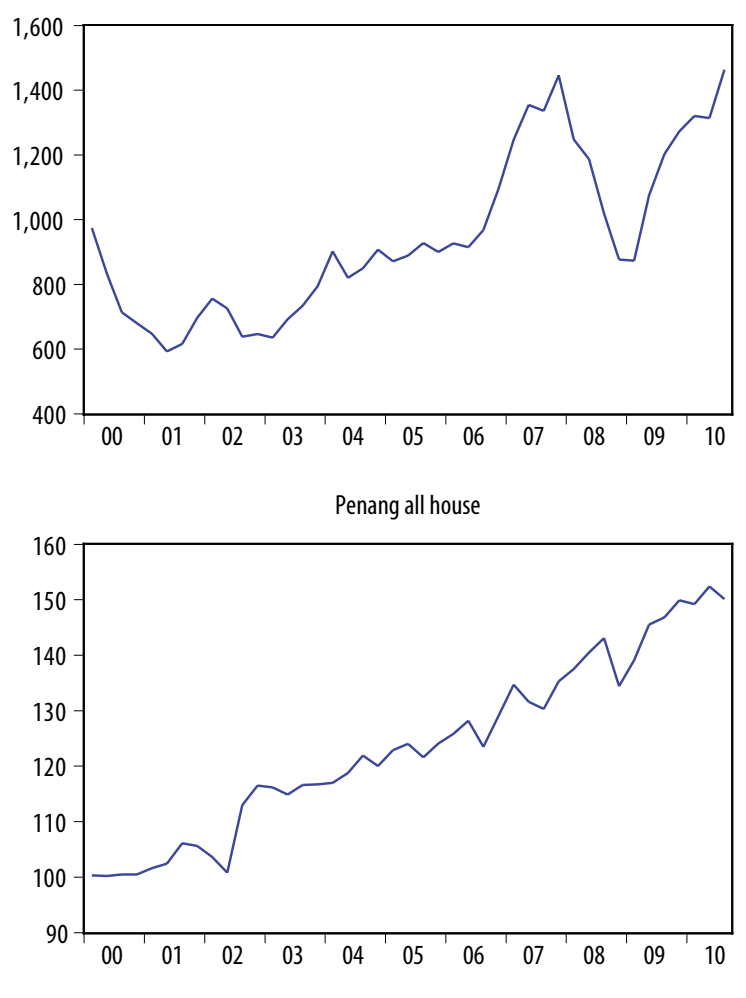

Kuala Lumpur all house

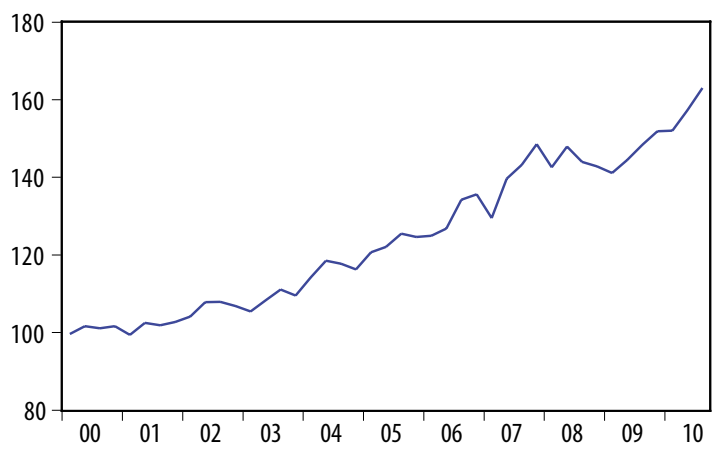

Fig. 1. Time series plots for interest rate, stock prices and house prices

Changes in house prices in Penang are most volatile followed by those in Kuala Lumpur and Selangor where volatility is measured by the standard deviation. The coefficients of variation show that the relative volatility of house prices in Penang is the highest especially for detached and semidetached houses.

\section{METHODOLOGY}

\subsection{Order of integration of the variables}

We first applied the standard Augmented Dickey Fuller (ADF) unit root test. Perron (1989) showed that the power to reject the null of a unit root decreases when the stationary alternative is true and a structural break is ignored. Hence, to further ex- amine the stationarity properties of the data for each series, we employed the lagrange multiplier (LM) unit root test with one structural break proposed by Lee and Strazicich (2003). In contrast to the Perron (1989) and Zivot and Andrews (1992) ADF-type unit root tests, the LM unit root test has the major advantage that its statistical properties are unaffected by the existence of a structural break under the null hypothesis (see Lee, Strazicich 2001). Lee and Strazicich (2003) developed two versions of the LM unit root test with one structural break. Using the same nomenclature as employed by Perron (1989), Model A is known as the 'crash' model, and allows for a one-time change in the intercept under the alternative hypothesis. Model C, the 'crash-cum-growth' model, allows for 
Table 1. Descriptive statistics of price changes

\begin{tabular}{|c|c|c|c|c|c|c|}
\hline & Mean & Std. Dev. & C.V. & Skewness & Kurtosis & Jarque-Bera \\
\hline Base lending rate (IR) & -0.0018 & 0.0333 & -18.3168 & -2.5207 & 13.0175 & 220.0913 \\
\hline KLCI (SP) & 0.0097 & 0.0915 & 9.4498 & -0.2666 & 2.4028 & 1.1217 \\
\hline Malaysia all & 0.0088 & 0.0107 & 1.2205 & 0.1496 & 3.2734 & 0.2874 \\
\hline Malaysia detached & 0.0113 & 0.0249 & 2.2183 & 0.2228 & 2.2157 & 1.4240 \\
\hline Malaysia semi-detached & 0.0097 & 0.0208 & 2.1493 & 0.7122 & 4.4634 & 7.2979 \\
\hline Malaysia terrace & 0.0086 & 0.0132 & 1.5494 & 0.0349 & 2.4797 & 0.4823 \\
\hline Malaysia high-rise & 0.0065 & 0.0332 & 5.1664 & 1.3461 & 10.3011 & 105.9689 \\
\hline Penang all & 0.0096 & 0.0283 & 2.9484 & 0.7314 & 6.3848 & 23.7942 \\
\hline Penang detached & -0.0005 & 0.1308 & -241.236 & 0.5419 & 2.9386 & 2.0624 \\
\hline Penang semi-detached & 0.0024 & 0.0498 & 20.4517 & 0.0759 & 4.0743 & 2.0600 \\
\hline Penang terrace & 0.0135 & 0.0416 & 3.0681 & -0.3688 & 3.3975 & 1.2287 \\
\hline Penang high-rise & 0.0092 & 0.0733 & 7.9500 & 2.1757 & 14.7685 & 275.5041 \\
\hline Selangor all & 0.0081 & 0.0193 & 2.3977 & -0.1020 & 2.7549 & 0.1779 \\
\hline Selangor detached & 0.0062 & 0.0662 & 10.6553 & -0.0340 & 3.2091 & 0.0846 \\
\hline Selangor semi-detached & 0.0080 & 0.0764 & 9.5314 & 0.2554 & 3.1074 & 0.4767 \\
\hline Selangor terrace & 0.0088 & 0.0213 & 2.4320 & -0.5275 & 4.7844 & 7.5200 \\
\hline Selangor high-rise & 0.0023 & 0.0355 & 15.6905 & -0.2052 & 4.4629 & 4.0397 \\
\hline Kuala Lumpur all & 0.0117 & 0.0255 & 2.1703 & -0.0534 & 2.8767 & 0.0466 \\
\hline Kuala Lumpur detached & 0.0167 & 0.0761 & 4.5465 & -0.2395 & 2.0405 & 2.0124 \\
\hline Kuala Lumpur semi-detached & 0.0135 & 0.1136 & 8.4201 & -0.2774 & 6.4500 & 21.3683 \\
\hline Kuala Lumpur terrace & 0.0116 & 0.0303 & 2.6166 & -0.2265 & 3.4322 & 0.6860 \\
\hline Kuala Lumpur high-rise & 0.0061 & 0.0331 & 5.4122 & 0.4331 & 2.1827 & 2.4821 \\
\hline
\end{tabular}

Note: The price changes are computed as first difference of the log value.

a shift in the intercept and a change in the trend slope under the alternative hypothesis (see Lee, Strazicich 2003 for more details). Sen (2003a) argued that Model C is preferable to Model A when the break date is treated as unknown. Further evidence from Monte Carlo simulations, reported in Sen (2003b), show that Model C will yield more reliable estimates of the breakpoint than Model A. Hence, we reported the results from Model C because it is the more general of the LM unit root tests.

To select the lag length, we used the general to specific procedure proposed by Hall (1994). We set the maximum number of lags equal to four and used the $10 \%$ asymptotic normal value of 1.645 to ascertain the statistical significance of the last first-differenced lagged term. After deciding the optimal lag length for each breakpoint, we ascertained the break where the endogenous LM statistic is at a minimum. The search is carried out over the trimming region $(0.15 \mathrm{~T}, 0.85 \mathrm{~T})$, where $\mathrm{T}$ is sample size. Critical values for the LM unit root test with one structural break are tabulated in Lee and Strazicich (2003).

\subsection{Cointegration and Granger causality}

Once the order of integration of each of the variables is ascertained, we proceed to test for cointegration. The existence of cointegration would imply that even though individual series may be non-stationary, one or more linear combinations of them are stationary. We employed the bounds approach to cointegration, which has three major advantages for our purposes (Pesaran, Shin 1999; Pesaran et al. 2001). First, the test is applicable irrespective of whether the variables are integrated of order zero $(\mathrm{I}(0))$ or integrated of order one (I(1). Because we have only a relatively small sample of 43 quarterly observations, the power of the unit root tests to distinguish between $\mathrm{I}(0)$ and I(1) processes is likely to be weakened. Using the bounds testing approach to cointegration helps to lessen this problem.

Second, the bounds test itself has good small sample properties and is frequently applied to sample sizes of 30 or less when used in conjunction with sample specific critical values. We employed the small sample critical values for the bounds test 
for 40 observations reported by Narayan (2005) in this study. The asymptotic distribution of the critical values is obtained for cases in which all regressors are purely I(1) as well as when the regressors are purely I(0) or mutually cointegrated. Third, the selection of an appropriate lag structure within the autoregressive distributed lag (ARDL) framework based on lag selection criteria is sufficient to correct for the problems of endogenous regressors and residual serial correlation.

To implement the bounds testing approach, we estimated the following Unrestricted Error-Correction Model (UECM):

$$
\begin{aligned}
& \Delta \ln \mathrm{HP}_{t}=\alpha+\beta_{1} \ln \mathrm{HP}_{t-1}+\beta_{2} \ln \mathrm{IR}_{t-1}+\beta_{3} \ln \mathrm{SP}_{t-1}+ \\
& \sum_{i=1}^{p} \gamma_{i} \Delta \ln \mathrm{HP}_{t-i}+\sum_{i=0}^{q} \delta_{i} \Delta \ln \mathrm{IR}_{t-i}+\sum_{i=0}^{r} \lambda_{i} \Delta \ln \mathrm{SP}_{t-i}+\varepsilon_{t},
\end{aligned}
$$

where: $\beta_{\mathrm{i}}$ are the long run parameters. The optimum lag orders for each estimation were chosen based on the Schwartz Bayesian Criteria (SBC) with a maximum lag of four. We tested the null hypothesis of no cointegration $\left(\mathrm{H}_{0}: \beta_{1}=\beta_{2}=\beta_{3}\right.$ $=0$ ) using an F-test. If the computed F-statistic exceeds the upper bound of the small sample critical values proposed by Narayan (2005), we concluded that the variables are cointegrated. If the F-statistic is below the lower bound of the critical values, the null hypothesis cannot be rejected. If the Fstatistic lies between its upper and lower bounds of critical values, the test is inconclusive. Long and short run coefficients can be derived from (1). Following Bardsen (1989), the long run coefficients for IR is $-\left(\beta_{2} / \beta_{1}\right)$ and for SP, it is $-\left(\beta_{3} / \beta_{1}\right)$. On the other hand, the short run coefficients for IR and SP are $\sum \delta_{i}$ and $\sum \lambda_{i}$ respectively from Equation (1).

Once it is established whether or not there is a long-run relationship between the series, we tested whether there is Granger causality between interest rates, house prices and stock prices. We employed a multivariate Granger causality test within the VAR framework to examine the dynamic relationship among the variables. If there is cointegration among the variables, the Granger causality procedure is based on the Vector Error Correction Model (VECM) where a one period lagged level of the error-correction term $\left(\mathrm{ECT}_{t-1}\right)$ is added in the system. This is to capture the shortrun deviations of series from their long-run equilibrium path.

$$
\left[\begin{array}{c}
\Delta \ln \mathrm{HP}_{t} \\
\Delta \ln \mathrm{IR}_{t} \\
\Delta \ln \mathrm{SP}_{t}
\end{array}\right]=\left[\begin{array}{c}
\alpha_{1} \\
\alpha_{2} \\
\alpha_{3}
\end{array}\right]+\left[\begin{array}{lll}
\mathrm{B}_{11,1} & \mathrm{~B}_{12,1} & \mathrm{~B}_{13,1} \\
\mathrm{~B}_{21,1} & \mathrm{~B}_{22,1} & \mathrm{~B}_{23,1} \\
\mathrm{~B}_{31,1} & \mathrm{~B}_{32,1} & \mathrm{~B}_{33,1}
\end{array}\right]\left[\begin{array}{c}
\Delta \ln \mathrm{HP}_{t-1} \\
\Delta \ln \mathrm{IR}_{t-1} \\
\Delta \ln \mathrm{SP}_{t-1}
\end{array}\right]+\ldots
$$

$$
\left[\begin{array}{lll}
\mathrm{B}_{11, k} & \mathrm{~B}_{12, k} & \mathrm{~B}_{13, k} \\
\mathrm{~B}_{21, k} & \mathrm{~B}_{22, k} & \mathrm{~B}_{23, k} \\
\mathrm{~B}_{31, k} & \mathrm{~B}_{32, k} & \mathrm{~B}_{33, k}
\end{array}\right]\left[\begin{array}{c}
\Delta \ln \mathrm{HP}_{t-k} \\
\Delta \ln \mathrm{IR}_{t-k} \\
\Delta \ln \mathrm{SP}_{t-k}
\end{array}\right]+\left[\begin{array}{c}
\rho_{1} \\
\rho_{2} \\
\rho_{3}
\end{array}\right] \times\left[\mathrm{ECT}_{t-1}\right]+\left[\begin{array}{c}
\varepsilon_{1 t} \\
\varepsilon_{2 t} \\
\varepsilon_{3 t}
\end{array}\right] .
$$

The ECT is estimated from the long run relationship as below:

$$
\mathrm{ECT}_{t}=\ln \mathrm{HP}_{t}-a-b_{1} \operatorname{lnIR}_{t}-b_{2} \operatorname{lnSP}_{t}
$$

Note, this is the long run part from Equation (1), not the whole Equation (1). The optimal lag orders (k) for the VAR/VECM model are selected using the minimum value of the SBC. Besides indicating the direction of Granger causality among variables, the VECM framework can also be used to distinguish between Granger short-run and long-run causality. The significance of the Wald $\chi^{2}$ statistic can be used to indicate any Granger shortrun causality between the independent variable and dependent variable. The existence of long-run Granger causality is indicated through the $\mathrm{ECT}_{t-1}$ where a significant t-statistic shows the existence of long-run Granger causality running from the independent variables to the dependent variable. We tested the null hypotheses below:

$$
\begin{aligned}
& \mathrm{H}_{01}: \mathrm{B}_{13,1}=\ldots=\mathrm{B}_{13, k}=0, \\
& \mathrm{H}_{02}: \mathrm{B}_{31,1}=\ldots=\mathrm{B}_{31, k}=0 .
\end{aligned}
$$

Rejecting $\mathrm{H}_{01}$, but not $\mathrm{H}_{02}$, suggests that stock prices Granger cause house prices. Rejecting $\mathrm{H}_{02}$, but not $\mathrm{H}_{01}$, suggests that house prices Granger cause stock prices. Rejecting both $\mathrm{H}_{01}$ and $\mathrm{H}_{02}$ suggests the existence of a feedback effect between house prices and stock prices.

\section{RESULTS}

Based on the ADF test, at the 5\% level or better, stock prices are $\mathrm{I}(0)$ and interest rates are $\mathrm{I}(1)$. Among house prices, some are $\mathrm{I}(0)$ and the rest are $\mathrm{I}(1)^{3}$. The results for the LM unit root test with one break in the intercept and slope (Model C) are reported in Table 2. Model C suggested that interest rates and stock prices are I(1) and that 14 of the 20 house price indices are $\mathrm{I}(0)$ at $5 \%$ or better. As there are time series for which the ADF unit root test and Model $\mathrm{C}$ give different results, it is useful to consider which results are preferable. As Ben-David et al. (2003) noted allowing for a break does not necessarily produce more rejections of the unit root null, because the critical value increases

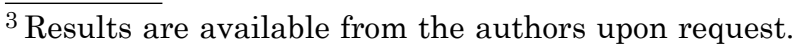


Table 2. LM unit root test with one structural break in the intercept and trend (Model C)

\begin{tabular}{|c|c|c|c|c|c|}
\hline & $\mathrm{TB}$ & $k$ & $\mathrm{~S}_{t-1}$ & $\mathrm{~B}_{t}$ & $\mathrm{D}_{t}$ \\
\hline BLR (IR) & 06Q1 & 1 & $\begin{array}{l}-0.2553 \\
(-2.7687)\end{array}$ & $\begin{array}{l}0.0330 \\
(1.1089)\end{array}$ & $\begin{array}{l}0.0039 \\
(0.4128)\end{array}$ \\
\hline KLCI (SP) & $01 Q 3$ & 2 & $\begin{array}{l}-0.4058 \\
(-3.9701)\end{array}$ & $\begin{array}{l}0.0824 \\
(1.1985)\end{array}$ & $\begin{array}{l}0.0768^{* * *} \\
(2.1795)\end{array}$ \\
\hline Malaysia all & 09Q2 & 0 & $\begin{array}{l}-0.5444 \\
(-3.9634)\end{array}$ & $\begin{array}{l}-0.0079 \\
(-0.7944)\end{array}$ & $\begin{array}{l}0.0077 \\
(1.6468)\end{array}$ \\
\hline Malaysia detached & 06Q1 & 0 & $\begin{array}{l}-0.5213 \\
(-3.8477)\end{array}$ & $\begin{array}{l}0.0303 \\
(1.4286)\end{array}$ & $\begin{array}{l}-0.0006 \\
(-0.0878)\end{array}$ \\
\hline Malaysia semi-detached & 04Q1 & 0 & $\begin{array}{l}-0.6611^{* * *} \\
(-4.5541)\end{array}$ & $\begin{array}{l}0.0246 \\
(1.4436)\end{array}$ & $\begin{array}{l}0.0069 \\
(1.2482)\end{array}$ \\
\hline Malaysia terrace & 08Q4 & 0 & $\begin{array}{l}-0.6632^{* * *} \\
(-4.5649)\end{array}$ & $\begin{array}{l}-0.0091 \\
(-0.8045)\end{array}$ & $\begin{array}{l}0.0034 \\
(0.7215)\end{array}$ \\
\hline Malaysia high-rise & 02Q3 & 0 & $\begin{array}{l}-0.6909^{* *} \\
(-4.7081)\end{array}$ & $\begin{array}{l}0.0204 \\
(0.7519)\end{array}$ & $\begin{array}{l}0.0098 \\
(0.9839)\end{array}$ \\
\hline Penang all & 03Q1 & 1 & $\begin{array}{l}-1.0517^{* * *} \\
(-5.5717)\end{array}$ & $\begin{array}{l}-0.0120 \\
(-0.5641)\end{array}$ & $\begin{array}{l}0.0278^{* * * *} \\
(2.9699)\end{array}$ \\
\hline Penang detached & 06Q2 & 2 & $\begin{array}{l}-1.5481^{* * *} \\
(-7.2181)\end{array}$ & $\begin{array}{l}-0.2963^{* * * *} \\
(-3.2836)\end{array}$ & $\begin{array}{l}0.3194^{* * * *} \\
(6.4371)\end{array}$ \\
\hline Penang semi-detached & 02Q3 & 0 & $\begin{array}{l}-0.6584^{* *} \\
(-4.5400)\end{array}$ & $\begin{array}{l}-0.0536 \\
(-1.3112)\end{array}$ & $\begin{array}{l}0.0498^{* * *} \\
(3.0247)\end{array}$ \\
\hline Penang terrace & 09Q1 & 0 & $\begin{array}{l}-0.8467^{* * *} \\
(-5.5531)\end{array}$ & $\begin{array}{l}0.0291 \\
(0.8582)\end{array}$ & $\begin{array}{l}0.0101 \\
(0.6786)\end{array}$ \\
\hline Penang high-rise & 02Q3 & 1 & $\begin{array}{l}-1.2161^{* * *} \\
(-5.7201)\end{array}$ & $\begin{array}{l}-0.2293^{* *} \\
(-2.2159)\end{array}$ & $\begin{array}{l}0.0391^{*} \\
(1.7573)\end{array}$ \\
\hline Selangor all & $05 \mathrm{Q} 2$ & 0 & $\begin{array}{l}-0.6295^{*} \\
(-4.3922)\end{array}$ & $\begin{array}{l}0.0425^{* *} \\
(2.5290)\end{array}$ & $\begin{array}{l}-0.0394^{* * * *} \\
(-3.7844)\end{array}$ \\
\hline Selangor detached & 06Q1 & 0 & $\begin{array}{l}-0.6734^{* *} \\
(-4.6171)\end{array}$ & $\begin{array}{l}-0.0490 \\
(-0.8703)\end{array}$ & $\begin{array}{l}0.0547^{* * * *} \\
(2.7918)\end{array}$ \\
\hline Selangor semi-detached & 04Q1 & 0 & $\begin{array}{l}-0.9747^{* * *} \\
(-6.3190)\end{array}$ & $\begin{array}{l}0.1705^{* * *} \\
(3.3099)\end{array}$ & $\begin{array}{l}-0.0211 \\
(-1.2725)\end{array}$ \\
\hline Selangor terrace & 04Q3 & 0 & $\begin{array}{l}-0.5098 \\
(-3.7907)\end{array}$ & $\begin{array}{l}0.0290 \\
(1.4850)\end{array}$ & $\begin{array}{l}-0.0403^{* * *} \\
(-3.3451)\end{array}$ \\
\hline Selangor high-rise & 08Q1 & 0 & $\begin{array}{l}-0.7574^{* *} \\
(-5.0599)\end{array}$ & $\begin{array}{l}-0.0782^{* * *} \\
(-2.8206)\end{array}$ & $\begin{array}{l}0.0162 \\
(1.6310)\end{array}$ \\
\hline Kuala Lumpur all & 06Q4 & 4 & $\begin{array}{l}-0.5806 \\
(-3.9544)\end{array}$ & $\begin{array}{l}-0.0749^{* * * *} \\
(-3.5296)\end{array}$ & $\begin{array}{l}0.0308^{* * * *} \\
(3.1723)\end{array}$ \\
\hline Kuala Lumpur detached & 02Q3 & 0 & $\begin{array}{l}-0.7744^{* * *} \\
(-5.1518)\end{array}$ & $\begin{array}{l}-0.1222^{* *} \\
(-2.1049)\end{array}$ & $\begin{array}{l}-0.0037 \\
(-0.1764)\end{array}$ \\
\hline Kuala Lumpur semi-detached & 07Q2 & 0 & $\begin{array}{l}-1.0309^{* * *} \\
(-6.6842)\end{array}$ & $\begin{array}{l}0.1067 \\
(1.3065)\end{array}$ & $\begin{array}{l}-0.0028 \\
(-0.1048)\end{array}$ \\
\hline Kuala Lumpur terrace & 08Q1 & 3 & $\begin{array}{l}-1.1267^{* * *} \\
(-4.9065)\end{array}$ & $\begin{array}{l}0.0486^{*} \\
(1.7996)\end{array}$ & $\begin{array}{l}-0.0251^{* * *} \\
(-2.6512)\end{array}$ \\
\hline Kuala Lumpur high-rise & 09Q2 & 0 & $\begin{array}{l}-0.5134 \\
(-3.8086)\end{array}$ & $\begin{array}{l}-0.0023 \\
(-0.0729)\end{array}$ & $\begin{array}{l}0.0465^{* * *} \\
(2.6916)\end{array}$ \\
\hline
\end{tabular}

Critical values for $\mathrm{S}_{t-1}$

\begin{tabular}{llllll}
\hline Location of break, $\lambda$ & 0.1 & 0.2 & 0.3 & 0.4 & 0.5 \\
\hline $1 \%$ significant level & -5.11 & -5.07 & -5.15 & -5.05 & -5.11 \\
$5 \%$ significant level & -4.50 & -4.47 & -4.45 & -4.50 & -4.51 \\
$10 \%$ significant level & -4.21 & -4.20 & -4.18 & -4.18 & -4.17 \\
\hline
\end{tabular}

Notes: TB is the date of the structural break; $k$ is the lag length; $\mathrm{S}_{\mathrm{t}-1}$ is the LM test statistic; $\mathrm{B}_{\mathrm{t}}$ is the dummy variable for the structural break in the intercept; $\mathrm{D}_{\mathrm{t}}$ is the dummy variable for the structural break in the slope. Figures in parentheses are $t$-values. The critical values for the LM test statistic are symmetric around $\lambda$ and $(1-\lambda)$. Critical values for other coefficients follow the standard normal distribution. ${ }^{*}\left({ }^{* *}\right){ }^{* * *}$ denote statistical significance at the $10 \%, 5 \%$ and $1 \%$ levels respectively. 
in absolute value. Comparing the LM unit root test with one break (Model C) with the ADF test, a rule of thumb is where the two give different results, Model C should be preferred if the break in the intercept and slope are significant. The break in the intercept and slope are significant for Penang detached and high-rise, Kuala Lumpur all housing and terrace and Selangor all housing. Hence, overall we concluded that stock prices are $\mathrm{I}(0)$ and interest rates are $\mathrm{I}(1)$, while 13 of the 20 house price series for Malaysia as a whole as well as for Kuala Lumpur, Penang and Selangor are either trend reverting or reverting around a segmented trend.

Turning to the location of the breakpoints, in Model C, most of the breakpoints in housing prices fall into one of four periods; namely, the recovery period following the recession of the early 2000 s (2002-2003) - five breaks; the property boom (2005-2006) - five breaks; GFC (2007-2008) - four breaks; or the recovery following the GFC (20092010) - three breaks. Many of the institutional changes discussed above, which were introduced in the wake of the GFC to stimulate demand, are likely associated with the breaks in 2009-2010. The break in stock prices occurs at the height of the recession of the early 2000 s, while the break in interest rates occurred in the middle of the property boom ${ }^{4}$.
The results of the ARDL bounds test for cointegration are reported in Table 3 . We report both the F-statistic and the long and short run coefficients for interest rates and stock prices. White's test is used to examine the presence of heteroscedasticity in the ARDL regression estimation. If heteroscedasticity is detected, the problem is corrected with the White heteroscedasticity-consistent variances. Only six house price indices are found to be cointegrated with the other two variables in the model. These house price indices are Penang detached, Penang semi-detached, Selangor semi-detached, Selangor high rise, Kuala Lumpur all houses and Kuala Lumpur semi-detached. Oikarinen (2010) found that substantial growth in foreign ownership of Finnish stocks induced a large, and long-lasting, deviation from the cointegrating long-run relation between stock and housing prices. In Malaysia's case the rapid growth in foreign ownership of property, combined with increasing foreign ownership of shares, may explain the lack of cointegration for Malaysia as a whole as well as specific indices in specific locations. Following Narayan and Smyth (2006), for robustness purposes, we also performed the analysis with inclusion of a time trend. The results are quantitatively similar to those reported in Table 3 and are available on request.

Table 3. ARDL bounds test for cointegration

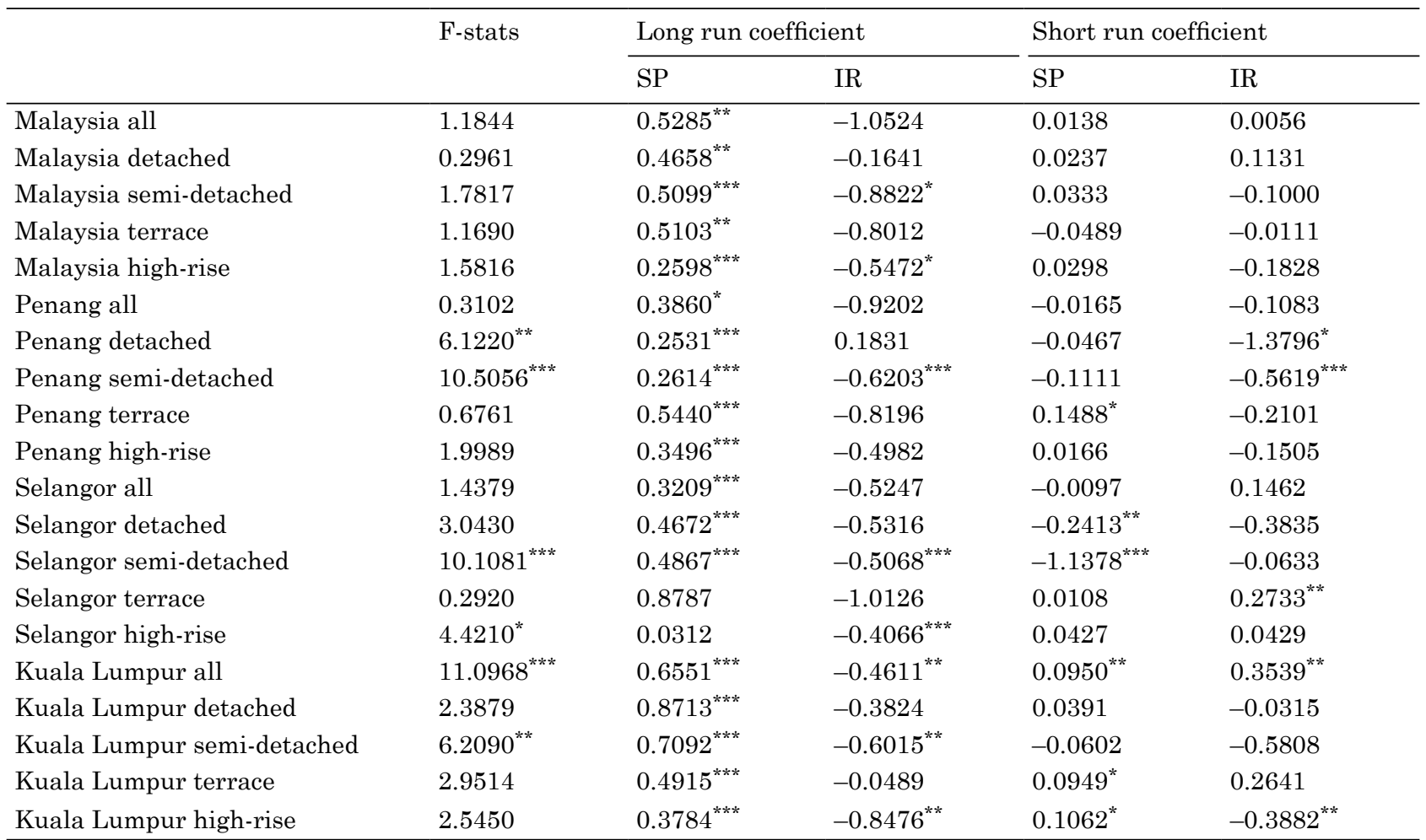

Notes: ${ }^{*}\left({ }^{* *}\right)\left({ }^{* * *}\right)$ denotes statistical significance at the 10(5)(1)\% level; Critical values for F-test are from Narayan (2005) with $k=2$ and $\mathrm{T}=40$, case III.

${ }^{4}$ On the unit root properties of housing prices in Malaysia, see also Lean and Smyth (2013a; 2013b). 
The long run coefficients for stock prices are positive, while for interest rates the long-run coefficients are negative. Results for short run coefficients are mixed, with many being insignificant. We also conducted the cointegration test for $\mathrm{HP}=$ $f(I R)$ and $S P=f(I R)$ to check whether one of the assets can be excluded from the long run relationship. For $\mathrm{HP}=\mathrm{f}(\mathrm{IR})$, only Selangor all houses was statistically significant at the $5 \%$ level with an $\mathrm{F}$ statistic $=6.8186$. For $\mathrm{SP}=\mathrm{f}(\mathrm{IR})$, the F-statistic $=$ 1.9184 was not significant. This implies both asset prices are needed in order to have a cointegrating relation in the system.

Table 4 shows $\chi^{2}$ statistics for the Granger causality test in the VAR/VECM framework and the coefficients for the lagged error correction term in the last column. The coefficients on the six lagged error correction terms are significant at the 5\% level or better with a negative sign, which confirms the finding from the cointegration test that there is a long-run relationship. This implies that changes in house prices are a function of disequilibrium in the cointegrating relationship. The coefficient on the error correction term denotes the speed of adjustment of house prices to the long run equilibrium. The adjustment speed ranges from 0.15 for Kuala Lumpur all housing to 0.93 for Penang detached. A value of 0.15 suggests that a deviation from the long-run equilibrium level of house prices in one quarter is corrected by about $15 \%$ in the next quarter. A value of 0.93 suggests that house prices adjust at $93 \%$ every quarter to restore equilibrium when there is shock on the steady-state relationship. Thus, given deviations from the longrun equilibrium, house prices adjust fairly fast. This result is similar to Ibrahim's (2010) study of the dynamic interaction between house prices and stock prices in Thailand, where the adjustment speed ranged from 0.26 to 0.87 .

Based on the error correction term, in the long run stock prices and interest rates Granger-cause house prices for Penang detached, Penang semidetached, Selangor semi-detached, Selangor highrise, Kuala Lumpur all and Kuala Lumpur semidetached. However, we cannot find any significant evidence that house prices and interest rates Granger-cause stock prices in these six cases. In other words, Granger causality runs interactively through the error correction term from both stock prices and interest rates to house prices. The longrun coefficients on stock prices suggest that an increase in stock prices has a positive effect on house prices. This result is consistent with a wealth effect or higher firm profitability being reflected in employee bonuses. However, since housing prices typically adjust to shocks in the economic fundamentals highly sluggishly and slower than stock prices, Granger causality between stock prices and housing prices can also be due to the slow adjustment of the housing market instead of the existence of any wealth effect. In other words, it could well be that the economic fundamentals are driving housing prices, but housing prices just react sluggishly to shocks in the fundamentals. This would be consistent with vast empirical evidence of the sluggish reaction of housing prices to changes in the fundamentals (see e.g. Clayton 1996; Himmelberg et al. 2005; Eickmeier, Hofmann 2010; Oikarinen et al. 2010 and the references cited therein).

In the short run, the evidence is much more mixed and there are no clear patterns. Stock prices Granger cause house prices for three house indices; house prices Granger cause stock prices for five house indices; there is bi-directional Granger causality for eight house indices and segmentation for four house indices. Previous studies have generally found support for the wealth effect in the short-run (Green 2002; Sutton 2002; Kapopoulos, Siokis 2005; Liu, Su 2010). Our findings are similar to those reported in Ibrahim (2010), who also used indices for a range of different types of housing for a single country. He also found that the direction of short-run Granger causality depended on which house price index is used.

Overall, for Malaysia as a whole housing and stock prices are segmented, while there is more evidence of stock prices leading house prices, consistent with a wealth effect, in Kuala Lumpur, Penang and Selangor. The finding of segmentation of the overall house price index for Malaysia might reflect the fact that it represents the average house price of all states, where some states are less developed and not financially advanced as compared to the three states examined. The most popular forms of housing for Malaysia's middle classes are terraces, followed by semi-detached and detached housing. The results for these specific types of housing for Malaysia as a whole are consistent with 'Mum' and 'Dad' investors leveraging of higher house prices to invest in the stock market.

For Penang, Kuala Lumpur and Selangor there is more evidence of stock market wealth leading housing wealth than for Malaysia as a whole. This finding reflects the fact that real estate in these states could be considered as an investment vehicle to a greater extent than in economically less de- 
Table 4. Granger causality results

\begin{tabular}{|c|c|c|c|c|c|c|}
\hline & & lag & $\mathrm{HP}$ & IR & $\mathrm{SP}$ & $\mathrm{ECT}_{t-1}$ \\
\hline MYA & $\begin{array}{l}\mathrm{HP} \\
\mathrm{IR} \\
\mathrm{SP}\end{array}$ & 1 & $\begin{array}{l}- \\
4.3795^{* *} \\
5.8839^{* *}\end{array}$ & $\begin{array}{l}2.9730^{*} \\
- \\
1.8473\end{array}$ & $\begin{array}{l}4.9463^{* *} \\
6.6488^{* * *} \\
-\end{array}$ & na \\
\hline MYD & $\begin{array}{l}\mathrm{HP} \\
\mathrm{IR} \\
\mathrm{SP}\end{array}$ & 1 & $\begin{array}{l}- \\
3.8888^{* *} \\
8.7924^{* * *}\end{array}$ & $\begin{array}{l}0.5891 \\
- \\
4.1231^{* *}\end{array}$ & $\begin{array}{l}5.1725^{* *} \\
6.1314^{* *} \\
-\end{array}$ & na \\
\hline MYH & $\begin{array}{l}\mathrm{HP} \\
\mathrm{IR} \\
\mathrm{SP}\end{array}$ & 1 & $\begin{array}{l}- \\
1.5587 \\
6.9191^{* * * *}\end{array}$ & $\begin{array}{l}2.4932 \\
- \\
1.5342\end{array}$ & $\begin{array}{l}2.5801 \\
3.5402^{*} \\
-\end{array}$ & na \\
\hline MYS & $\begin{array}{l}\mathrm{HP} \\
\mathrm{IR} \\
\mathrm{SP}\end{array}$ & 2 & $\begin{array}{l}- \\
8.0553^{* *} \\
7.9625^{* *}\end{array}$ & $\begin{array}{l}5.6472^{*} \\
- \\
1.4458\end{array}$ & $\begin{array}{l}4.0182 \\
10.1829^{* * *} \\
-\end{array}$ & na \\
\hline MYT & $\begin{array}{l}\mathrm{HP} \\
\mathrm{IR} \\
\mathrm{SP}\end{array}$ & 1 & $\begin{array}{l}- \\
4.5553^{* *} \\
4.5863^{* *}\end{array}$ & $\begin{array}{l}1.9512 \\
- \\
1.8814\end{array}$ & $\begin{array}{l}4.7053^{* * *} \\
6.8549^{* * *} \\
-\end{array}$ & na \\
\hline KLA & $\begin{array}{l}\mathrm{HP} \\
\mathrm{IR} \\
\mathrm{SP}\end{array}$ & 3 & $\begin{array}{l}- \\
4.7236 \\
5.6730\end{array}$ & $\begin{array}{l}6.0584 \\
- \\
2.5778\end{array}$ & $\begin{array}{l}6.4881^{*} \\
4.4752 \\
-\end{array}$ & $\begin{array}{l}-0.1533^{\text {***}} \\
-0.3874^{* * *} \\
0.5751\end{array}$ \\
\hline KLD & $\begin{array}{l}\text { HP } \\
\text { IR } \\
\text { SP }\end{array}$ & 3 & $\begin{array}{l}\overline{7.6201^{*}} \\
6.5123^{*}\end{array}$ & $\begin{array}{l}3.5687 \\
- \\
2.3668\end{array}$ & $\begin{array}{l}9.5214^{* * *} \\
8.3260^{* *} \\
-\end{array}$ & na \\
\hline $\mathrm{KLH}$ & $\begin{array}{l}\mathrm{HP} \\
\mathrm{IR} \\
\mathrm{SP}\end{array}$ & 1 & $\begin{array}{l}- \\
1.3798 \\
2.1166\end{array}$ & $\begin{array}{l}3.4850^{*} \\
- \\
1.2211\end{array}$ & $\begin{array}{l}3.0175^{*} \\
2.8838^{*} \\
-\end{array}$ & na \\
\hline KLS & $\begin{array}{l}\mathrm{HP} \\
\mathrm{IR} \\
\mathrm{SP}\end{array}$ & 1 & $\begin{array}{l}- \\
3.4433^{*} \\
3.3334^{*}\end{array}$ & $\begin{array}{l}0.6232 \\
- \\
3.3517^{*}\end{array}$ & $\begin{array}{l}0.1472 \\
0.9872 \\
-\end{array}$ & $\begin{array}{l}-0.4884^{* * * *} \\
-0.1493^{* * *} \\
0.2891\end{array}$ \\
\hline KLT & $\begin{array}{l}\mathrm{HP} \\
\mathrm{IR} \\
\mathrm{SP}\end{array}$ & 1 & $\begin{array}{l}- \\
3.0134^{*} \\
4.8808^{* *}\end{array}$ & $\begin{array}{l}0.5999 \\
- \\
4.1906^{* *}\end{array}$ & $\begin{array}{l}3.8788^{* * *} \\
5.1179^{* *} \\
-\end{array}$ & na \\
\hline PGA & $\begin{array}{l}\mathrm{HP} \\
\mathrm{IR} \\
\mathrm{SP}\end{array}$ & 1 & $\begin{array}{l}- \\
3.5494^{*} \\
6.8520^{* * *}\end{array}$ & $\begin{array}{l}0.8504 \\
- \\
1.5971\end{array}$ & $\begin{array}{l}0.5664 \\
5.7861^{* *} \\
-\end{array}$ & na \\
\hline PGD & $\begin{array}{l}\mathrm{HP} \\
\mathrm{IR} \\
\mathrm{SP}\end{array}$ & 1 & $\begin{array}{l}- \\
1.8215 \\
0.5180\end{array}$ & $\begin{array}{l}4.5080^{* *} \\
- \\
2.9084^{*}\end{array}$ & $\begin{array}{l}0.8781 \\
3.2438^{*} \\
-\end{array}$ & $\begin{array}{l}-0.9302^{\text {*** }} \\
-0.1003 \\
0.0901\end{array}$ \\
\hline PGH & $\begin{array}{l}\mathrm{HP} \\
\mathrm{IR} \\
\mathrm{SP}\end{array}$ & 1 & $\begin{array}{l}- \\
2.2490 \\
6.7337^{* * * *}\end{array}$ & $\begin{array}{l}1.0537 \\
- \\
3.7750^{*}\end{array}$ & $\begin{array}{l}2.8183^{*} \\
4.4443^{* *} \\
-\end{array}$ & na \\
\hline PGS & $\begin{array}{l}\mathrm{HP} \\
\mathrm{IR} \\
\mathrm{SP}\end{array}$ & 1 & $\begin{array}{l}- \\
0.0951 \\
1.4465\end{array}$ & $\begin{array}{l}0.2480 \\
- \\
4.5913^{* *}\end{array}$ & $\begin{array}{l}1.3556 \\
2.6401 \\
-\end{array}$ & $\begin{array}{l}-0.7606^{\text {**** }} \\
0.0389 \\
0.4584\end{array}$ \\
\hline PGT & $\begin{array}{l}\mathrm{HP} \\
\mathrm{IR} \\
\mathrm{SP}\end{array}$ & 1 & $\begin{array}{l}- \\
2.7807^{*} \\
5.0158^{* *}\end{array}$ & $\begin{array}{l}0.6408 \\
- \\
1.4266\end{array}$ & $\begin{array}{l}0.3065 \\
4.9007^{* *} \\
-\end{array}$ & na \\
\hline SGA & $\begin{array}{l}\mathrm{HP} \\
\mathrm{IR} \\
\mathrm{SP}\end{array}$ & 1 & $\begin{array}{l}- \\
3.0224^{*} \\
2.9632^{*}\end{array}$ & $\begin{array}{l}5.6289^{* *} \\
- \\
3.1619^{*}\end{array}$ & $\begin{array}{l}14.2456^{* * *} \\
5.2509^{* *} \\
-\end{array}$ & na \\
\hline SGD & $\begin{array}{l}\mathrm{HP} \\
\mathrm{IR} \\
\mathrm{SP}\end{array}$ & 1 & $\begin{array}{l}- \\
2.9946^{*} \\
0.5844\end{array}$ & $\begin{array}{l}0.0052 \\
- \\
6.4163^{* *}\end{array}$ & $\begin{array}{l}8.6907^{* * * *} \\
5.0773^{* * *} \\
-\end{array}$ & na \\
\hline SGH & $\begin{array}{l}\mathrm{HP} \\
\mathrm{IR} \\
\mathrm{SP}\end{array}$ & 1 & $\begin{array}{l}- \\
4.3160^{* *} \\
0.0185\end{array}$ & $\begin{array}{l}0.1495 \\
- \\
3.2816^{*}\end{array}$ & $\begin{array}{l}1.9341 \\
3.2927^{*} \\
-\end{array}$ & $\begin{array}{l}-0.6491^{\text {*** }} \\
-0.1098 \\
0.3462\end{array}$ \\
\hline SGS & $\begin{array}{l}\mathrm{HP} \\
\mathrm{IR} \\
\mathrm{SP}\end{array}$ & 1 & $\begin{array}{l}- \\
7.5106^{* * *} \\
0.2423\end{array}$ & $\begin{array}{l}2.8282^{*} \\
- \\
3.4840^{*}\end{array}$ & $\begin{array}{l}1.6528 \\
1.4684 \\
-\end{array}$ & $\begin{array}{l}-0.5242^{\text {****}} \\
-0.1492^{\text {***}} \\
0.3266\end{array}$ \\
\hline SGT & $\begin{array}{l}\mathrm{HP} \\
\mathrm{IR} \\
\mathrm{SP}\end{array}$ & 1 & $\begin{array}{l}- \\
3.2903^{*} \\
3.0480^{*}\end{array}$ & $\begin{array}{l}5.1220^{* *} \\
- \\
3.2465^{*}\end{array}$ & $\begin{array}{l}11.6975^{* * *} \\
5.5461^{* *} \\
-\end{array}$ & na \\
\hline
\end{tabular}

Notes: ${ }^{* * *}{ }^{* * * *}$ denote statistical significance at the $10 \%, 5 \%$ and $1 \%$ levels respectively. A = 'all houses'; D = 'detached houses'; $\mathrm{S}=$ 'semi-detached houses'; $\mathrm{T}=$ 'terrace houses'; $\mathrm{H}=$ 'high-rise houses'; HP = house prices; IR = base lending rate; $\mathrm{SP}=$ Kuala Lumpur Composite Index. 
veloped states. Specifically, both states and Kuala Lumpur are among the most popular for foreigners investing in the Malaysian property market. Kapopoulos and Siokis (2005), in their study of house and stock price interaction in Greece, also found evidence of a wealth effect in Athens, in which there is a lot of investment in real estate, while other urban areas in Greece exhibited a creditprice effect. In addition, housing in Kuala Lumpur, Penang and Selangor is relatively expensive compared with the rest of Malaysia. As noted by Green (2002) more expensive markets are prime candidates for the wealth effect to be large.

\section{CONCLUSIONS}

This study has examined the dynamic linkages between house prices and stock prices in Malaysia. For Malaysia as a whole there is no long-run relationship between house prices and stock prices. One is more likely to expect evidence consistent with a wealth effect in specific locations where there is high income pockets and relatively expensive real estate (Green 2002). Consistent with this perspective, there is much more evidence of stock prices leading house prices, consistent with a wealth effect, in the developed regions of Kuala Lumpur, Penang and Selangor. In these states, compared with the Malaysian average, housing is relatively expensive, income is relatively high and real estate is used much more as an investment vehicle by both wealthy Malaysians and foreigners who are more likely to leverage of shares. It is important to emphasize, though, that where stock prices lead house prices this is at best consistent with a wealth effect. The finding that stock market returns Granger cause housing returns does not prove a wealth effect per se, since the lead-lag relation can be explained by other factors as well. Other possible explanations include sluggish adjustment of house prices in response to a shock in the fundamentals.

With this proviso in mind, the fact that stock prices lead house prices for six house price indices across the three developed regions, tends to put the stock market centre stage and suggests that the stock market is important for stability in the real estate market, at least in the developed regions. This result is similar to Ibrahim's (2010) findings for Thailand. He argued that the burst in the Thai housing market following the Asian financial crisis in 1997-1998 was a result of declining stock markets. The result is also consistent with the findings in Mun et al. (2008) that the stock market Granger causes economic growth in Malaysia. The policy implication of finding evidence consistent with a wealth effect for six house price indices across Kuala Lumpur, Penang and Selangor is that policymakers should implement policies to promote stability in the stock market. Along these lines, Securities Commission Malaysia launched a five-year Corporate Governance Blueprint in July 2011, which provides an action plan to raise the standards of corporate governance in Malaysia by strengthening self, and market, discipline and promoting greater internalisation of the culture of good governance (see Securities Commission Malaysia 2011). The Blueprint focuses on six connected themes of the corporate governance ecosystem; namely, shareholder rights, the roles of institutional investors, boards, gatekeepers and influencers, disclosure and transparency as well as public and private enforcement.

\section{ACKNOWLEDGEMENT}

The authors would like to acknowledge the Universiti Sains Malaysia Short Term Research Grant No. 304/PSOSIAL/6311120.

\section{REFERENCES}

Bardsen, G. 1989. Estimation of long run coefficients in error correction models, Oxford Bulletin of Economics and Statistics 51(3): 345-450.

http://dx.doi.org/10.1111/j.1468-0084.1989.mp51003008.x

Barot, B.; Takala, K. 1998. House prices and inflation: a cointegration analysis for Finland and Sweden, Bank of Finland Discussion Papers 12/98, Helsinki, Finland.

Ben-David, D.; Lumsdaine, R.; Papell, D. 2003. Unit root, postwar slowdowns and long-run growth: evidence from two structural breaks, Empirical Economics 28: 303-319.

Bryson, J.; Kamaruddin, Y. 2010. 2010: year of the Tiger or Asian bubble?, Wells Fargo Securities, January 28. Available at: http://wellsfargo.com/research [accessed 19 July 2010]

Chen, N.-K. 2001. Asset price fluctuations in Taiwan: evidence from stock and real estate prices 1973 to 1992, Journal of Asian Economics 12(2): 215-232. http://dx.doi.org/10.1016/S1049-0078(01)00083-5

Chou, C.-C.; Chen, S.-L. 2011. Integrated or segmented? A wavelet transform analysis on relationship between stock and real estate markets, Economics Bulletin 31(4): 3030-3040.

Ciarlone, A. 2011. Housing wealth effect in emerging economies, Emerging Markets Review 12(4): 399417. http://dx.doi.org/10.1016/j.ememar.2011.06.003

Clayton, J. 1996. Rational expectations, market fundamentals and housing price volatility, Real Estate Economics 24(4): 441-470.

http://dx.doi.org/10.1111/1540-6229.00699 
EIU. 2011. Malaysia five-year forecast table, Economic Intelligence Unit (EIU), London, 1 April, 2011.

Englund, P.; Hwang, M.; Quigley, J. M. 2002. Hedging housing risk, Journal of Real Estate Finance and Economics 24: 167-200. http://dx.doi.org/10.1023/A:1013942607458

Eichholtz, P.; Hartzell, D. 1996. Property shares, appraisals and the stock market: an international perspective, Journal of Real Estate Finance and Economics 12(2): 163-178. http://dx.doi.org/10.1007/BF00132265

Eickmeier, S.; Hofmann, B. 2010. Monetary policy, housing booms and financial imbalances, European Central Bank Working Paper No. 1178.

Fu, Y.; Ng, L. K. 2001. Market efficiency and return statistics: evidence from real estate and stock markets using a present-value approach, Real Estate Economics 29(2): 227-250.

http://dx.doi.org/10.1111/1080-8620.00009

Gharaibeh, M.; Alrabadi, D. 2012. Stock and real estate markets: the case of Dubai, International Research Journal of Finance and Economics (100): 63-74.

Green, R. 2002. Stock prices and house prices in California: new evidence of a wealth effect?, Regional Science and Urban Economics 32(6): 775-783. http://dx.doi.org/10.1016/S0166-0462(01)00103-X

Gyourko, J.; Keim, D. B. 1992. What does the stock market tell us about real estate returns?, Real Estate Economics 20(3): 457-485. http://dx.doi.org/10.1111/1540-6229.00591

Guo, F.; Huang, Y.-S. 2010. Does 'hot money' drive China's real estate and stock markets?, International Review of Economics and Finance 19(3): 452-466. http://dx.doi.org/10.1016/j.iref.2009.10.014

Hall, A. D. 1994. Testing for a unit root in time series with pretest data based model selection, Journal of Business and Economic Statistics 12(4): 461-470. http://dx.doi.org/10.1080/07350015.1994.10524568

Hartzell, D. 1986. Real estate in the portfolio, in Fabozzi, F. J. (Ed.) The Institutional investor: focus on investment management. Balliger: Cambridge, MA.

Himmelberg, C.; Mayer, C.; Sinai, T. 2005. Assessing high house prices, bubbles, fundamentals and misperceptions, National Bureau of Economic Research Working Paper 11643.

Ho, C. S. 2008. Urban governance and rapid urbanization issues in Malaysia, Jurnal Alam Bina 13(4): $1-24$.

Hoesli, M.; Hamelink, F. 1997. An examination of the role of Geneva and Zurich housing in Swiss institutional portfolios, Journal of Property Valuation and Investment 15(4): 354-371. http://dx.doi.org/10.1108/14635789710693182

Hui, E. C. M.; Ng, I. M. H. 2012. Wealth effect, credit price effect and the inter-relationships between Hong Kong's property market and stock market, Property Management 30(3): 255-273. http://dx.doi.org/10.1108/02637471211233864

Hui, H. C. 2009. The impact of property market developments on the real economy of Malaysia, International Research Journal of Finance and Economics (30): 66-86.
Ibbotson, R.; Siegel, L. 1984. Real estate returns: a comparison with other investments, Real Estate Economics 12(3): 219-242.

http://dx.doi.org/10.1111/1540-6229.00320

Ibrahim, M. H. 2010. House price-stock price relations in Thailand: an empirical analysis, International Journal of Housing Markets and Analysis 3(1): 6982. http://dx.doi.org/10.1108/17538271011027096

Kakes, J.; Van Den End, J. W. 2004. Do stock prices affect house prices? Evidence for the Netherlands, Applied Economics Letters 11(12): 741-744. http://dx.doi.org/10.1080/1350485042000254863

Kapopoulos, P.; Siokis, F. 2005. Stock and real estate prices in Greece: wealth versus 'credit-price' effect, Applied Economics Letters 12(2): 125-128. http://dx.doi.org/10.1080/1350485042000307107

Khan, T. S. 2010. Asian housing markets: bubble trouble? East Asia and Pacific Division, World Bank, Washington.

Lean, H. H.; Smyth, R. 2013a. Regional house prices and the ripple effect in Malaysia, Urban Studies 50(5): 895922. http://dx.doi.org/10.1177/0042098012459582

Lean, H. H.; Smyth, R. 2013b. Do Malaysian house prices follow a random walk? Evidence from univariate and panel LM unit root tests with one and two structural breaks, Applied Economics 45(18): 2611-2627. http://dx.doi.org/10.1080/00036846.2012.674207

Lee, J.; Strazicich, M. C. 2001. Break point estimation and spurious rejections with endogenous unit root tests, Oxford Bulletin of Economics and Statistics 63(5): 535-558. http://dx.doi.org/10.1111/1468-0084.00234

Lee, J.; Strazicich, M. C. 2003. Minimum Lagrange multiplier unit root test with two structural breaks, $R e$ view of Economics and Statistics 85(4): 1082-1089. http://dx.doi.org/10.1162/003465303772815961

Lin, T. C.; Lin, Z. H. 2011. Are stock and real estate markets integrated? An empirical study of six Asian economies, Pacific-Basin Finance Journal 19(5): 571585. http://dx.doi.org/10.1016/j.pacfin.2011.05.001

Liu, Y. S.; Su, C. W. 2010. The relationship between the real estate and stock markets of China: evidence from a nonlinear model, Applied Financial Economics 20(22): 1741-1749. http://dx.doi.org/10.1080/09603107.2010.524616

Markowitz, H. 1952. Portfolio selection, Journal of Finance 7(1): 77-91. http://dx.doi.org/10.1111/j.1540-6261.1952.tb01525.x

Mun, H. W.; Long, B. S.; Siong, E. C.; Thing, T. C. 2008. Stock market and economic growth in Malaysia: causality test, Asian Social Science 4(4): 86-92.

Mun, N. 2010. High cost of land reason for steep high prices in Penang, says Rehda, Bernama Daily Malaysian News, 9 December, 2010.

Narayan, P. 2005. The savings and investment nexus for China: evidence from cointegration tests, Applied Economics 37(17): 1979-1990. http://dx.doi.org/10.1080/00036840500278103

Narayan, P.; Smyth, R. 2006. Higher education, real income and real investment in China: evidence from Granger causality tests, Education Economics 14(1): 107-125. http://dx.doi.org/10.1080/09645290500481931 
$\mathrm{Ng}$, A. 2006. Housing and mortgage markets in Malaysia, in B. Kusmiarso (Ed.) Housing and Mortgage Markets in SEACEN countries, SEACEN Publication, 123-188.

Oikarinen, E. 2009. Interaction between housing prices and household borrowing: the Finnish case, Journal of Banking and Finance 33(4): 747-756. http://dx.doi.org/10.1016/j.jbankfin.2008.11.004

Oikarinen, E. 2010. Foreign ownership of stocks and long-run interdependence between national housing and stock markets - evidence from Finnish data, Journal of Real Estate Finance and Economics 41(4): 486-509. http://dx.doi.org/10.1007/s11146-009-9175-1

Oikarinen, E.; Hoesli, M.; Serrano, C. 2010. Response speeds of direct and securitized real estate to shocks in the fundamentals, Discussion paper No. 60, Abao Centre for Economics.

Ortalo-Magné, F.; Rady S. 2006. Housing market dynamics: on the contribution of income shocks and credit constraints, Review of Economic Studies 73(2): $459-485$. http://dx.doi.org/10.1111/j.1467-937X.2006.383_1.x

Perron, P. 1989. The great crash, the oil price shock and the unit root hypothesis, Econometrica 57(6): 1361-1401.

Pesaran, M. H.; Shin, Y. 1999. An autoregressive distributed lag modeling approach to cointegration analysis, in Strom, S. (Ed.) Econometrics and Economic Theory in the 20 $0^{\text {th }}$ Century: The Ragnar Frisch Centennial Symposium. Cambridge: Cambridge University Press.

Pesaran, M. H.; Shin, Y.; Smith, R. J. 2001. Bounds testing approaches to the analysis of level relationships, Journal of Applied Econometrics 16(3): 289-326. http://dx.doi.org/10.1002/jae.616

Piazzesi, M.; Schneider, M.; Tuzel, S. 2007. Housing, consumption and asset pricing, Journal of Financial Economics 83(3): 531-569.

http://dx.doi.org/10.1016/j.jfineco.2006.01.006

Quan, D. C.; Titman, S. 1999. Do real estate prices and stock prices move together? An international analy- sis, Real Estate Economics 27(2): 183-207.

http://dx.doi.org/10.1111/1540-6229.00771

Securities Commission Malaysia. 2011. Corporate governance blueprint 2011: towards excellence in corporate governance. Securities Commission Malaysia, Kuala Lumpur.

Sen, A. 2003a. On unit-root tests when the alternative is a trend-break stationary process, Journal of Business and Economics Statistics 21(1): 174-84.

http://dx.doi.org/10.1198/073500102288618874

Sen, A. 2003b. Some aspects of the unit root testing methodology with application to real per capita GDP, Xavier University, Cincinnati, $\mathrm{OH}$.

Sim, S.-H.; Chang, B.-K. 2006. Stock and real estate markets in Korea: wealth or credit-price effect, Journal of Economic Research 11: 99-122.

Sivalingam, G. 2011. Is there a housing bubble in Malaysia? Available at: http://findarticles.com/p/articles/ mi_qn6207/is_20110201/ai_n56942311/ [accessed 7 April 2011]

Sutton, G. D. 2002. Explaining changes in house prices, BIS Quarterly Review September: 46-55.

Takala, K.; Pere, P. 1991. Testing the cointegration of house and stock prices in Finland, Finnish Economic Papers 4(1): 33-51.

Williams, C. H.; Talhar; Wong. 2012. WTW Property Market 2012. C. H. Williams Talhar and Wong: Kuala Lumpur.

World Bank. 2008. East Asia: testing times ahead. Washington DC: World Bank.

Worzala, E.; Vandell, K. 1993. International direct real estate investments as alternative portfolio assets for institutional investors: an evaluation, paper presented at the 1993 AREUEA meeting, Anaheim, CA.

Zivot, E.; Andrews, D. 1992. Further evidence of the great crash, the oil-price shock and the unit-root hypothesis, Journal of Business and Economic Statistics 10(3): 251-270. http://dx.doi.org/10.1080/07350015.1992.10509904 